\title{
A Quantitative Study of the Deposition and Clearance of Bacteria in the Murine Lung *
}

\author{
G. A. Laurenzi, L. Berman, M. First, and E. H. Kass \\ (From the Channing Laboratory, Thorndike Memorial Laboratory, Second and Fourth [Har- \\ vard] Medical Services, and Mallory Institute of Pathology, Boston City \\ Hospital, and the Departments of Bacteriology and Immunology, \\ Medicine, and Pathology, Harvard University Medical School, \\ Boston, Mass.)
}

Recent bacteriologic studies have shown that the bronchial secretions of human beings are usually sterile in the absence of evident bronchopulmonary disease (1-3). However, bacterial contamination of the bronchi by inspired air, and perhaps by upper respiratory tract secretions, can be considered to be a common occurrence. For example, when radiopaque media are instilled into the pharynges of sleeping individuals, radiopacity can often be detected in the lungs afterward (4). Thus, the absence of bacteria in the bronchi suggests that potent antibacterial mechanisms are continuously operative (3).

The capacity of bronchopulmonary tissue to dispose of foreign materials, including bacteria, has been recognized for many years. Stillman (5) and Hamburger and Robertson (6) observed that pneumococci disappeared from the peripheral portions of the lungs of mice and dogs within a few hours after sprays of pneumococci had been instilled. On the other hand, oropharyngeal commensals and potential respiratory pathogens can be isolated from the bronchial secretions of patients with chronic bronchitis during relatively quiescent periods in their disease, i.e., in the absence of increased symptomatology and signs of infection (3). The bacteria that are found in such secretions are usually present in numbers exceeding $10^{6}$ colonies per milliliter of secretions (3). Such a finding implies impairment of the antibacterial mechanisms of the respiratory tract in chronic bronchitis and indicates the need for further study of the mechanisms by which the

* Submitted for publication October 17, 1963 ; accepted December 19, 1963.

Aided by grants from the National Institutes of Health, U. S. Public Health Service (AI 3901), and the New York Tuberculosis and Health Association. bronchopulmonary system retains its sterility. Presumably, insight into such mechanisms would provide a basis for understanding better the pathogenesis of chronic bronchopulmonary infection.

The present study was designed to investigate the quantitative implantation and clearance of aerosolized bacteria in the lungs of small animals. Many early experiments with airborne contagion employed coarse sprays and systems that were difficult to quantitate. Precise aerosol-exposure systems were introduced by Wells, who demonstrated that droplet nuclei play a key role in the aerial transmission of disease $(7,8)$. Bacteria in minute-dried residues of evaporated droplets live suspended in air for hours, and in this state they are inhaled and deposited in pulmonary tissue. Aerosol devices were further developed in large-scale cloud chamber studies (9). Lurie, Heppleston, Abramson, and Swartz (10) and Middlebrook (11) also adapted these techniques to the experimental production of pulmonary tuberculosis. Most of the experimental equipment for such studies is complex and costly. This report describes an inexpensive, compact aerosol exposure system that offers a relatively simple method for the deposition of predictable numbers of bacteria in the lungs of small animals and the quantitative study of the clearance of bacteria from the respiratory tract.

\section{Methods}

The exposure apparatus is illustrated in Figure 1. An aerosol is generated by a nebulizer which contains bacteria in a liquid suspension. The aerosol is then drawn into a large air volume in which the liquid particles are rapidly dried and carried to the experimental animals. The effluent is discarded after being passed through bacterial filters. 


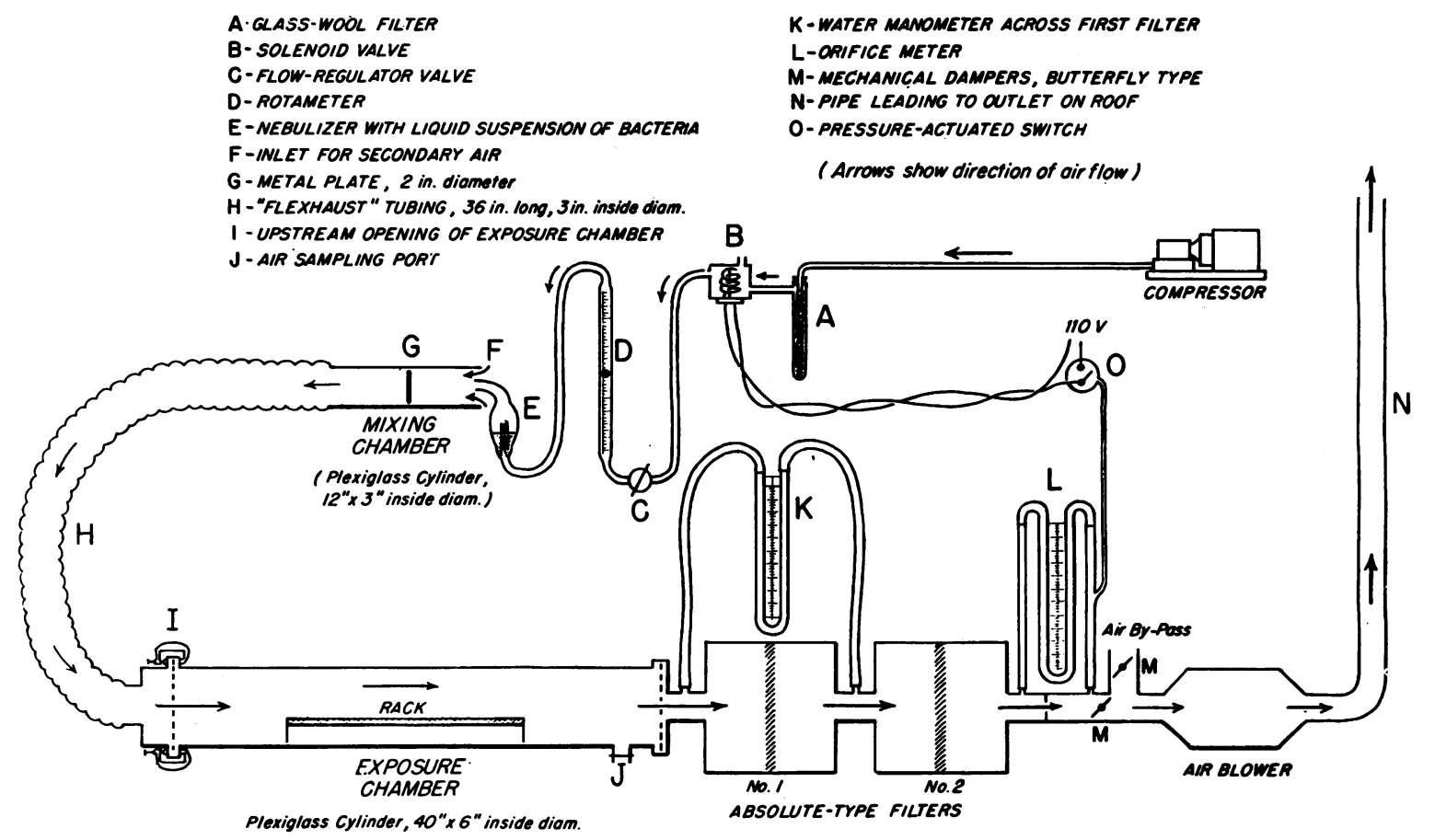

Fig. 1. Aerosol exposure apparatus.

\section{Aerosol-generating apparatus}

Compressed air, flowing at the rate of $6 \mathrm{~L}$ per minute, is passed through a De Vilbiss 40 nebulizer ${ }^{1}$ which contains a liquid suspension of bacteria. This process produces a cloud of small liquid droplets $85 \%$ of which have a particle diameter of $3.3 \mu$ or less (12). Flow is measured with a calibrated rotameter, and the rate is controlled by a screw clamp located between the compressor and rotameter. A glass-wool filter (no. 800 Pyrex laboratory glass wool) is placed in the line upstream from the rotameter to remove dust and lubricants from the air. The outlet of the nebulizer is directed into the open end of a hollow plexiglas tube. This cylinder is the mixing chamber in which the bacterial cloud from the nebulizer is mixed with a larger volume of air. The secondary air enters the mixing chamber around the nozzle of the nebulizer, and it dilutes and dries the spray. A blower located at the downstream end of the apparatus maintains the secondary airflow at 5 cubic feet per minute. At the center of the mixing chamber, a circular metal disc is suspended perpendicularly to the stream. This baffle removes the large droplets and provides more uniform mixing of the bacteria in the air. The stream of finely divided aerosolized particles passes through the space between the metal baffle and the inner surface of the mixing tube.

\section{Exposure chamber}

The chamber is a large plexiglass cylinder whose transparency makes it convenient to observe the test animals during a run. It is equipped with removable ends

\footnotetext{
1 The De Vilbiss Co., Somerset, $\mathrm{Pa}$.
}

and a small port for air sampling. A perforated plastic rack with a receptacle for mouse droppings fits into the cylinder.

\section{Filter and evacuation system}

Two bacterial filters ${ }^{2}$ are placed in series downstream from the exposure chamber on the negative pressure side of the blower. The blower is capable of delivering 75 cubic feet of air per minute against a resistance of 30 inches of water. Airflow is regulated by mechanical dampers and measured by an orifice meter. The effluent is vented to the outside through a pipe extending 12 feet above the highest point of the building.

\section{Safety precautions}

Care must be taken to protect the workers and the general community from bacterial aerosols. The apparatus is installed in a well-ventilated room, and traffic into and out of the room is kept at a minimum. The apparatus is operated only by individuals who have familiarized themselves completely with the equipment and procedures. Surgical gown, cap, and gloves are worn as a safeguard against contact infection. Before the removal of animals from the exposure chamber, the operators don full face masks equipped with bacterial filters. ${ }^{3}$ The entire apparatus is kept under negative pressure when in operation to prevent the escape of infected air. Whenever the exposure chamber is opened, the flow is increased by valves to produce a minimal velocity of 75 cubic feet per minute of air through the opening.

2 6C10-A-N2Na, Flanders Filter, Inc., Riverhead, N. Y.

${ }^{3}$ Mine Safety Appliances Co., Pittsburgh, $\mathrm{Pa}$. 
The bacterial penetration through a single filter of the type used is reported to be less than 1 per 100 million organisms at the fitration velocity employed (13). Two filters in series provide an additional safety factor. A U-tube manometer is mounted across the first filter to measure a potential change in pressure that wou'd indicate failure of the filter by rupture or occlusion. No change in filter resistance was noted during the course of the present experiments.

Since a failure of the blower while the aerosol generator is in operation might result in the escape of organisms into the laboratory, a safety valve is installed in the compressed air line to the nebulizer. The solenoid valve is activated by a pressure switch connected to a pressure tap located upstream from the main system. The valve is normally open when flow through the exposure chamber is adequate. However, when the secondary airflow decreases, the valve closes and diverts the air from the upstream compressor away from the nebulizer. As a further precaution all joints between sections of the test apparatus are reinforced with rubber tubing and sealed with hose clamps or electrical tape. Ultraviolet lights are instailed in the laboratory to disinfect the room air. If pathogenic bacteria are being aeroso.ized, the aerosol-generating apparatus and exposure chamber may be housed in a gloved box made of plexiglass.

\section{Preparation of bacterial suspension}

The organism used was a coagulase-positive strain of Staphylococcus aureus (FDA 209P, type 42D). White Swiss mice weighing 20 to $25 \mathrm{~g}$ were exposed to aerosols of this organism, and the numbers of bacteria in the nebulizer suspensions, exposure chamber air, and lungs of the animals were determined. By reference to the growth curve for this strain of bacteria, it was possible to decide on a procedure that would insure a reproducible concentration of bacteria in the suspension for the nebulizer. A loopful of bacteria from an agar slant was inoculated into $100 \mathrm{ml}$ of nutrient broth. The broth was incubated for 12 hours at $37^{\circ} \mathrm{C}$ in an agitated water bath. A loopful of the broth culture was then inoculated into a second flask of broth, and the 12-hour growth in the second flask was used to prepare the nebulized suspension. A few experiments were done with broth dilutions of the bacteria, but most experiments were carried out with suspensions of staphylococci in 0.1 $\mathrm{M}$ potassium phosphate buffer ( $\mathrm{pH} 7.3)$. Twenty-ml vol of broth cultures containing $1-2 \times 10^{9}$ staphylococci per $\mathrm{ml}$ were centrifuged at $6,000 \mathrm{rpm}$ for 20 minutes in an anglehead centrifuge. The supernatant liquid was poured off, and the sedimented bacteria were washed with $10 \mathrm{ml}$ of buffer. The bacteria were then resuspended in appropriate amounts of buffer, and $6 \mathrm{ml}$ of the buffered suspension of bacteria was placed in the reservoir of the nebulizer.

\section{General operation and experiments}

When mice are exposed to rapid air currents, they have a tendency to huddle and cover their external nares. To circumvent this, each mouse was placed in a small rubber mesh envelope. The borders of the mesh were stapled together, and care was taken to make the envelopes large enough so that respirations were not restricted. At the end of each run the stapled borders could be easily pulled apart, and the mice removed quickly. The mice were placed in the mesh envelopes 1 hour before each run. After 45 minutes they were placed in the exposure chamber, and the air blower was turned on. Fifteen minutes later the nebulizer was started, and the flow rates into the neubulizer and through the chamber were adjusted. The exposure period for most runs was 30 minutes. At the end of this time, the nebulizer was turned off, and the flow through the main system was increased to 15 cubic feet per minute. A period of 10 seconds was allowed to elapse to effect one complete change of air in the parts upstream from the exposure chamber; then the upstream end of the exposure chamber was opened, and the mice were removed. The high flow rate was maintained for 10 minutes longer to clear the apparatus and to prepare it for another run.

Immediately after the mice were removed, they were killed by clamping the tracheae externally with hemostats. This method was used to prevent agonal aspiration of pharyngeal contents. The animals were then immersed in a 1:1,000 solution of aqueous benzalkonium chloride for 10 minutes to decontaminate their coats. The lungs were removed aseptically and homogenized in high speed glass homogenizers containing samples of nutrient broth. The tissues that were homogenized included the lungs and all intrapulmonary bronchi; the trachea and proximal portions of the main stem bronchi were excluded. Pour plates of nutrient agar were made with dilutions of the bacterial suspensions and of the homogenates. These were incubated at $37^{\circ} \mathrm{C}$ for 24 hours, and the colonies were counted in the usual manner. Bacterial retention (and clearance) was determined by counting the numbers of bacteria in the lungs of mice sacrificed at 1-, 2-, 3-, 4-, 6-, 8-, 10-, 12-, and 24-hour intervals after exposure.

The bacterial content of exposure chamber air was determined by collecting multiple air samples at the rate of 0.1 cubic feet per minute in midget samplers, ${ }^{4}$ containing $10 \mathrm{ml}$ of phosphate buffer and 2 drops of sodium alginate (14). Colony counts were performed on the samples of air obtained in this manner.

Histologic sections were made of the lungs of mice at the designated times after exposure to bacterial aerosols. The lungs were fixed in buffered formalin and stained by standard methods.

\section{Definition of terms}

Nebulizer concentration. The number of bacteria per milliliter of diluent in the nebulizer before nebulization.

Loading concentration. The calculated number of bacteria per cubic foot of air aerosolized from the nebulizer suspension. It is determined on the basis of the volume of nebulizer fluid used during the exposure period, diluted with 5.5 cubic feet of air per minute.

${ }^{4}$ Mine Safety Appliances Co., Pittsburgh, Pa. 
TABLE I

The influence of suspending medium and of bacterial concentration in the nebulizer on concentration of staphylococci in chamber air

\begin{tabular}{|c|c|c|c|c|}
\hline \multirow[b]{2}{*}{$\begin{array}{l}\text { Suspension } \\
\text { media }\end{array}$} & \multirow[b]{2}{*}{$\begin{array}{l}\text { Staphylococci } / \mathrm{ml} \\
\text { in nebulizer* }\end{array}$} & \multicolumn{3}{|c|}{ Chamber air concentration } \\
\hline & & $\begin{array}{c}\text { Measured } \\
\text { Staphylococci/ } \\
\text { cubic } \mathrm{ft} .\end{array}$ & $\begin{array}{l}\text { Calculated } \\
\text { Staphylococci/ } \\
\text { cubic ft. }\end{array}$ & $\frac{\text { Measured }}{\text { Calculated }} \times 100$ \\
\hline Buffer & $\begin{array}{l}\text { no. } \\
1.6 \times 10^{7} \\
1.6 \times 10^{8} \\
1.6 \times 10^{9}\end{array}$ & $\begin{array}{l}\text { no. } \\
1.3 \times 10^{5} \\
1.5 \times 10^{6} \\
2.0 \times 10^{7}\end{array}$ & $\begin{array}{l}\text { no. } \\
4.0 \times 10^{5} \\
4.0 \times 10^{6} \\
4.0 \times 10^{7}\end{array}$ & $\begin{array}{l}\% \\
33 \\
38 \\
50\end{array}$ \\
\hline Broth & $\begin{array}{l}4.6 \times 10^{6} \\
2.2 \times 10^{7} \\
4.3 \times 10^{7} \\
4.3 \times 10^{8}\end{array}$ & $\begin{array}{l}9.5 \times 10^{3} \\
2.4 \times 10^{4} \\
8.6 \times 10^{3} \\
4.3 \times 10^{3}\end{array}$ & & \\
\hline
\end{tabular}

* In this and in subsequent tables, numbers of staphylococci will refer to numbers of colonies counted.

Exposure chamber aerosol concentration. The number of bacteria per cubic foot of exposure chamber air. This is derived from the numbers of bacteria collected in the fluid of the air samplers and corrected for the volume of air sampled.

Inhaled number. The calculated number of bacteria inhaled by each mouse. This is determined by the formula

$\frac{\text { Ce.c. } \times \text { M.R.V. } \times t}{28.3 \times 10^{3}}=$ inhaled number of bacteria,

where Ce.c. $=$ bacteria per cubic foot exposure chamber air, M.R.V. = minute respiratory volume of mouse $(28$ $\mathrm{ml}$ per minute), calculated on the basis of the average

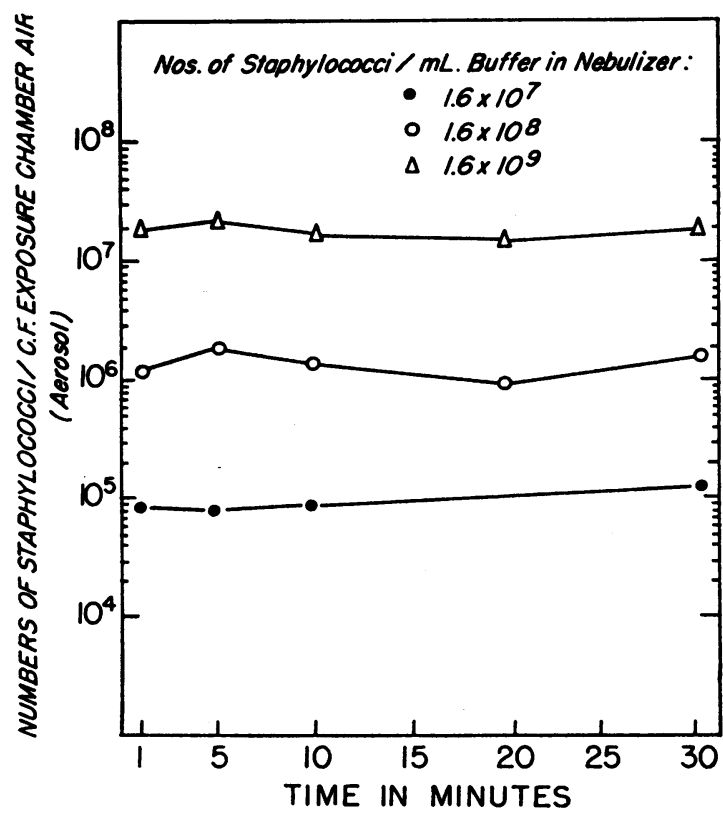

Fig. 2. NUMBERS OF STAPHYLOCOCCI PER CUBIC FOOT EXPOSURE CHAMBER AIR (AEROSOL) GENERATED OVER A 30-MINUTE PERIOD FROM THREE DIFFERENT CONCENTRATIONS OF BUFFER-SUSPENDED STAPHYLOCOCCI. minute respiratory volume for $20 \mathrm{-g}$ mice $(15), t=\mathrm{ex}-$ posure time in minutes, and 28.3 refers to $28.3 \mathrm{~L}=1$ cubic foot.

The bacterial content of lungs and intrapulmonary bronchi was measured as the number of colonies of viable bacteria in the lungs at the end of the exposure period. It represents the total number deposited in the lungs minus the unknown number of deposited organisms that were killed or cleared during the exposure period. An additional number of bacteria, present in the smallest aerosol particles, can be presumed to have been inspired and expired again without deposition.

\section{Results}

Aerosol studies. The suspension of staphylococci in buffer was superior to that in broth for purposes of the present studies. In the buffer, the concentration of staphylococci remained constant to within $1.0 \%$ over a 2 -hour period at room temperature. During aerosolization there was a maximal increase of $0.5 \%$ in bacterial numbers in the buffer suspension that remained in the nebulizer reservoir. The concentration of staphylococci in broth was more variable, and bacterial multiplication was often observed. Foaming was barely visible in the buffer solution, but was obviously substantial with broth. During 30 minutes of nebulization a mean volume of 3.8 $\mathrm{ml} \pm 0.02 \mathrm{ml}$ of buffer suspension was used (range, 3.0 to $4.3 \mathrm{ml}$ ). The broth mixture went through much more rapidly, so that it was usually necessary to refill the reservoir of the nebulizer after 15 minutes. The concentration of bacteria in aerosols generated from buffer mixtures was higher than in those produced from broth suspensions (Table I). The losses in bacterial viability 
due to aerosolization were relatively small. At 1 $\times 10^{9}$ bacteria per $\mathrm{ml}$ of buffer suspension the concentration of bacteria in the aerosol (loading concentration) was $50 \%$ of the calculated value. At $1 \times 10^{8}$ bacteria per $\mathrm{ml}$ in the nebulizer the loading concentration was $38 \%$ of the calculated value, and similarly at $1 \times 10^{7}$ the concentration of bacteria in the aerosol was $33 \%$ of the maximal possible value.

Samples of buffered aerosols were taken at different times from the exposure chamber air over a 30-minute period, and the results are shown in Figure 2. The maximal concentration of aerosol in the air is reached almost immediately, and the levels are then maintained. A linear relationship between numbers of staphylococci in the buffer and the numbers in the air of the exposure chamber is seen.

Bacterial deposition and retention. During exposure periods the respiratory rates of the mice vary between 150 and 250 per minute. A comparison between the numbers of staphylococci

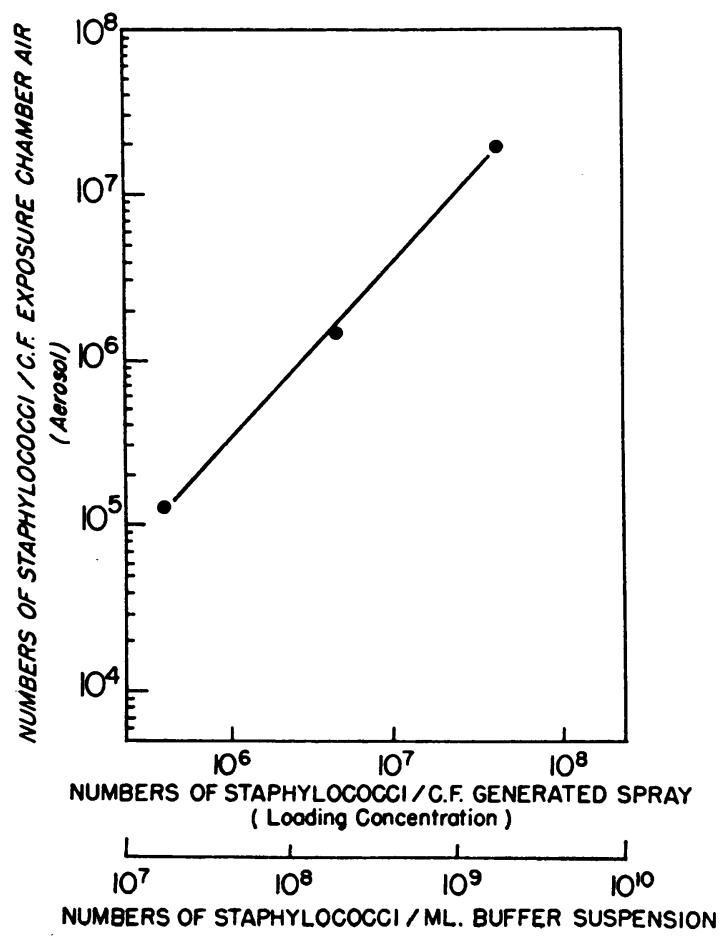

Fig. 3. Relationship of the NUMBERS OF STAPHyLoCOCCI IN BUFFER SUSPENSIONS, THE CALCULATED NUMBERS OF STAPHYLOCOCCI IN THE GENERATED SPRAY, AND THE NUMBERS OF STAPHYLOCOCCI IN THE CHAMBER AFTER 30 MINUTES OF NEBLLIZATION.

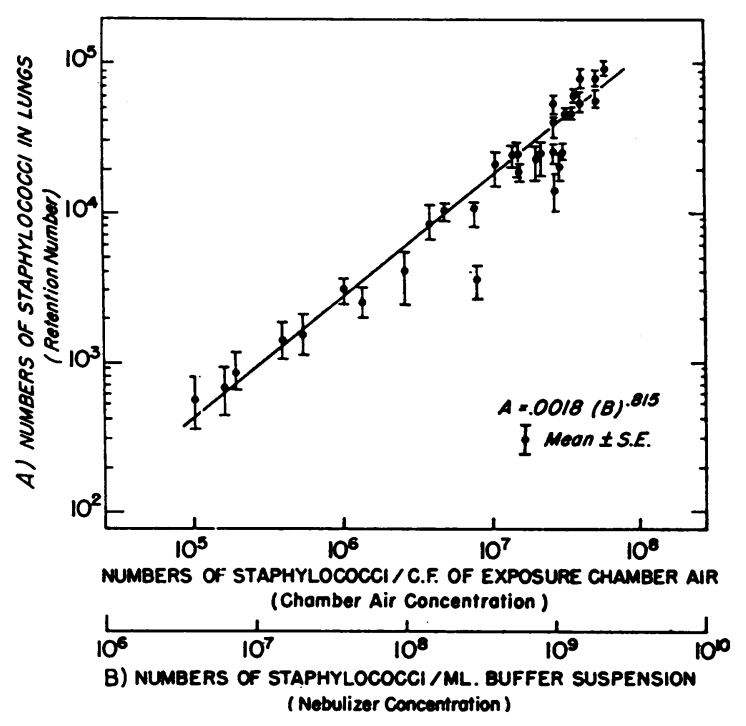

Fig. 4. Relationship OF THE NUMBERS OF STAPHYLOCOCCI PER MILLILITER OF BUFFER SUSPENSION (NEBULIZER CONCENTRATION), THE NUMBERS OF STAPHYLOCOCCI PER CUBIC FOOT OF EXPOSURE CHAMBER AIR (AEROSOL), AND THE NUMBERS OF STAPHYLOCOCCI RETAINED IN THE LUNGS OF MICE (RETENTION NUMBER) IMMEDIATELY AFTER 30 MINUTES OF EXPOSLRE.

found in the lungs of mice at the upstream and downstream ends of the exposure chamber showed no consistent pattern of difference. However, wide differences and smaller numbers of organisms in the lungs were found in animals in the lower tier in the preliminary experiments in which the animals were stacked in the exposure chamber. The variability was probably due to the poorer circulation of air in the crowded areas.

The numbers of staphylococci found in the lungs of mice killed after 30 minutes of exposure to aerosols generated from various concentrations of bacteria in the nebulizer are shown in Figure 3. A linear relationship exists between the log numbers of bacteria in the nebulizer and the log numbers of staphylococci in the chamber, for nebulizer concentrations of $3 \times 10^{6}$ to $2 \times 10^{9}$ bacteria per $\mathrm{ml}$. In other studies, mice exposed to buffer-generated aerosols had consistently more bacteria in their lungs than those exposed to brothgenerated clouds containing similar numbers of organisms. Figure 4 shows the relationship of staphylococcal numbers in the nebulizer to the numbers in the exposure chamber air and in the murine lungs. Thus, the numbers of bacteria in the nebulizer, the aerosol, and the lungs are di- 


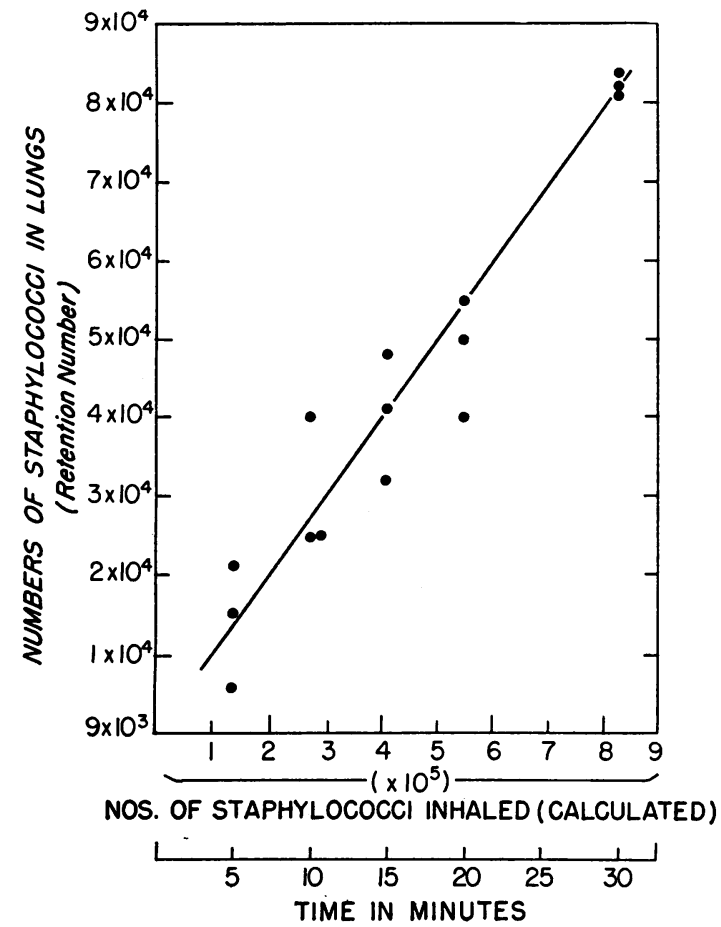

Fig. 5. Relationship Between the NUMBERS OF STAPHYLOCOCCI RETAINED IN LUNGS OF MICE AND THE NUMBERS OF STAPHYLOCOCCI INHALED (CALCULATED) AT VARIOUS TIME INTERVALS DURING 30 MINUTES OF EXPOSURE TO AN AEROSOL GENERATED FROM A BUFFER SUSPENSION (NEBULIZER) OF $2.0 \times 10^{\circ}$ STAPHYLOCOCCI PER MILLILITER.

rectly related to one another; the bacterial concentrations in the air and in the lungs rise in linear fashion in response to increasing concentrations of bacteria in the nebulizer.

The numbers of staphylococci in the lungs of the mice were determined at different time intervals during a 30-minute exposure to buffergenerated aerosols, and the results are shown in Figure 5. There is a constant rate of increase in the numbers of bacteria in lungs during the exposure period, but the numbers of bacteria found after 30 minutes are less variable than the num- bers after shorter exposure periods. The numbers of staphylococci inhaled by the mice during the exposure period can be calculated, and from this the percentage of bacteria retained at the end of 30 minutes of exposure can be derived (Table II). The percentage of inhaled bacteria found in mouse lungs is relatively low: $10 \%$ at an air concentration of $2.0 \times 10^{7}$ staphylococci per cubic foot, and $36 \%$ at a concentration of $1.3 \times 10^{5}$ staphylococci per cubic foot of air. Although the latter figure is not corrected for the amount of bacterial killing that must have occurred during the 30-minute exposure time, at the higher concentrations of organisms the efficiency of deposition is somewhat impaired.

The numbers of viable bacteria remaining in the lungs of mice were studied at intervals following the 30-minute exposure period, and the data are given in Tables III and IV. The numbers of bacteria retained in the lungs are expressed as the proportion of the numbers found immediately after exposure in animals exposed simultaneously. Figure 6 shows the clearance curve constructed from these data. Within 1 hour after the termination of exposure to the aerosol, the lungs were cleared of $43 \%$ of the bacteria that were present at the end of the exposure period. After 2 hours, $68 \%$ of the bacteria were cleared; at 3 hours, $82 \%$; and at 6 hours, $95 \%$ of the bacteria were cleared from the lungs of mice.

Routine histologic sections of the lungs after 30 minutes of exposure and at hourly intervals thereafter showed no evidence of pneumonia. The staphylococci could not be identified in ordinary histologic preparations. The only significant morphologic changes that were noted consisted of focal areas of increased septal cellularity composed largely of polymorphonuclear leukocytes. The presence or degree of this finding could not be correlated with the length of time fol-

TABLE II

Relationship of staphylococcal concentrations in nebulizer buffer to numbers found in exposure chamber air numbers inhaled, and numbers in lungs after 30 minutes' exposure time

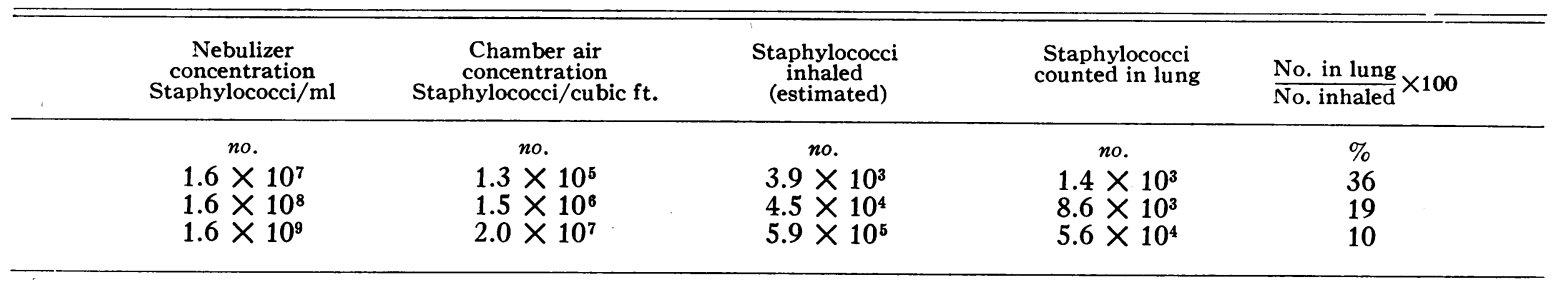


lowing exposure or the numbers of bacteria retained.

Statistical considerations. The model in analysis of the data on bacterial clearance assumes a constant rate $(v)$ of inhalation of bacteria during the exposure of the mouse to the bacterial aerosol. A constant death rate $(u)$ per bacterium present in the lung per hour is also assumed. From this the mean number of bacteria $\left(m_{0}\right)$ retained immediately after exposure should be:

$$
m_{0}=\frac{v}{u}\left(1-e^{-u i}\right),
$$

where $i$ is the duration of exposure. At time $(t)$ after exposure, the mean number of bacteria $\left(m_{t}\right)$ retained should be:

$$
m_{t}=\frac{v}{u}\left(1-e^{-u i}\right) e^{-u t}
$$

According to the model, the variance of each number of bacteria is equal to the mean number of bacteria. However, heterogeneity of the animals implies larger variances than the model would predict. This allows an estimation of variance for $v$ and $u$.

Thus, for example, from the counts of bacteria, the mean and its standard error are computed (Table IV) :

$\begin{array}{ccc}\text { Time } & \text { Mean } & \text { Standard error } \\ 0 & m_{0}=10,300 & s_{0}=1,634 \\ 1 & m_{t}=5,150 & s_{t}=1,015 \\ 0 & m_{0}=38,438 & s_{0}=7,669 \\ 1 & m_{t}=24,214 & s_{t}=2,797 \\ 0 & m_{0}=61,250 & s_{0}=6,471 \\ 1 & m_{t}=35,000 & s_{t}=4,714\end{array}$

The proportion of bacteria remaining at time $(t)$ $=p_{t}=m_{t} / m_{0}$. The proportion of bacteria cleared is $1-p_{t}$. The variance of each $p_{t}$ is $v_{t}=\left(s_{t} / m_{0}\right)^{2}$ $+p_{t}\left(s_{0} / m_{0}\right)^{2}$, approximately. Therefore:

$$
\begin{array}{cccr}
p_{1} & v_{1} & p_{1}-\bar{p}_{1} & \left(p_{1}-\bar{p}_{1}\right)^{2} \\
50.0 \% & 160.0(\%)^{2} & -6.7 \% & 44.8 \% \%^{2} \\
63.0 \% & 211.0(\%)^{2} & +6.3 \% & 39.7 \% \%^{2} \\
57.1 \% & 95.6(\%)^{2} & +0.4 \% & 0.2 \%{ }^{2} \\
\frac{17.1 \%}{p_{1}=170.1 \%} & v_{1}=466.6(\%)^{2} & & \left.p_{1}-\bar{p}_{1}\right)^{2}=84.7 \% \%^{2} \\
\bar{p}_{1}=56.7 \% & \bar{v}_{1}=155.5(\%)^{2} & & \\
r=\text { no. of runs, } 3 \text { in this case. } & (1 / r-1) & \left(p_{1}-\bar{p}_{1}\right)^{2} \\
= & 42.3 \% \%^{2} .
\end{array}
$$

The "within variance" listed in Table IV is $v_{t}$ (the average of the $v_{t}$ ): the variances of the proportions. Therefore, $v_{t}$ measures the
TABLE III

The numbers of viable staphylococci remaining in murine lungs at various times after exposure to aerosols of bacteria

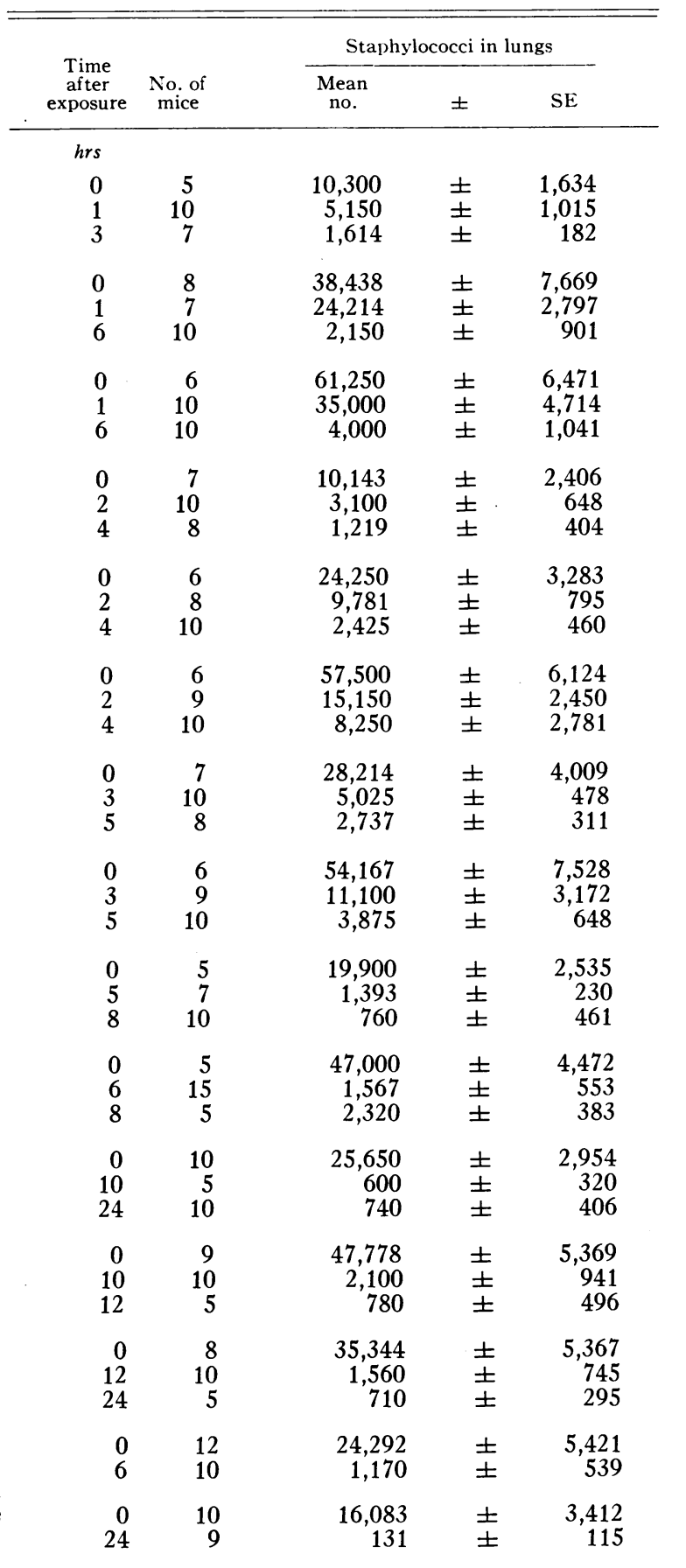

variation among the animals on a given run at a given time. For example: $160 \%^{2}$ is the variance of the proportion cleared due to variation among the animals run at times 0 to 1 . The 
TABLE IV

The hourly clearance of staphylococci from the lungs of mice (and the numbers of staphylococci remaining) expressed as the proportion (\%) of staphylococci originally retained immediately after exposure

\begin{tabular}{|c|c|c|c|c|c|}
\hline \multirow{2}{*}{$\begin{array}{l}\text { Time after } \\
\text { end of } \\
\text { 30-minute } \\
\text { exposure }\end{array}$} & \multicolumn{2}{|c|}{ Proportion of staphylococci } & \multirow[b]{2}{*}{$\mathrm{SE}$} & \multicolumn{2}{|c|}{ Variance } \\
\hline & Remaining* & Cleared & & Within & Between \\
\hline hrs & $\%$ & $\%$ & $\%$ & \multicolumn{2}{|c|}{$\%$ squared } \\
\hline 0 & 100.0 & 00.0 & & & \\
\hline 1 & 56.7 & 43.3 & 8.1 & 155.50 & 42.30 \\
\hline 2 & 32.4 & 67.6 & 5.3 & 33.70 & 51.50 \\
\hline $\begin{array}{l}2 \\
3\end{array}$ & $\begin{array}{l}32.4 \\
17.9\end{array}$ & 82.1 & 2.8 & 18.89 & 5.30 \\
\hline 4 & 12.1 & 87.9 & 2.7 & 18.45 & 4.63 \\
\hline 5 & 7.9 & 92.1 & 1.3 & 2.56 & 2.29 \\
\hline 6 & 5.0 & 94.9 & 1.3 & 4.79 & 1.86 \\
\hline 8 & 4.4 & 95.6 & 1.4 & 3.14 & .63 \\
\hline 10 & 3.4 & 96.6 & 1.2 & 2.88 & 2.12 \\
\hline 12 & 3.0 & 97.0 & 1.9 & 3.00 & 3.86 \\
\hline 24 & 1.4 & 98.6 & .8 & .67 & .72 \\
\hline
\end{tabular}

* (No. of staphylococci remaining/no. of staphylococci originally found) $\times 100$.

"between variance" is $(1 / r-1)\left(p_{t}-\bar{p}_{t}\right)^{2}$, which is $42.3 \%^{2}$ in our sample calculation. This is simply the sample variance of the proportions at time 1 hour. Each proportion comes from a different run, so the "between variance" measures variation from run to run. If the between variance were significantly greater than the within variance, we would conclude that these are real differences among the proportions from different runs. However, this is not the case. Both within and between variances in Table IV are variances of a single proportion. The total variance for a single proportion is the sum of the within and between variances. The variance of the mean proportion listed in Table IV is the total variance for a single proportion divided by the number of proportions ( 3 , in our example). The standard error of the mean proportion (column 4 in Table IV) is the square root of this variance of the mean proportion. Thus, total variance for a single proportion $=\bar{v}_{t}+(1 / r-1)\left(p_{t}-\bar{p}_{t}\right)^{2}$ $=\left(155.5+42.3 \%{ }^{2}=197.8 \% \%^{2}\right.$.

Total variance for the mean proportion $=$ total variance for a single proportion $=197.8 / 3 \%{ }^{2}=$ $65.9 \%{ }^{2}$. Standard error for the mean proportion $=\sqrt{65.9} \%^{2}=8.11 \%$.

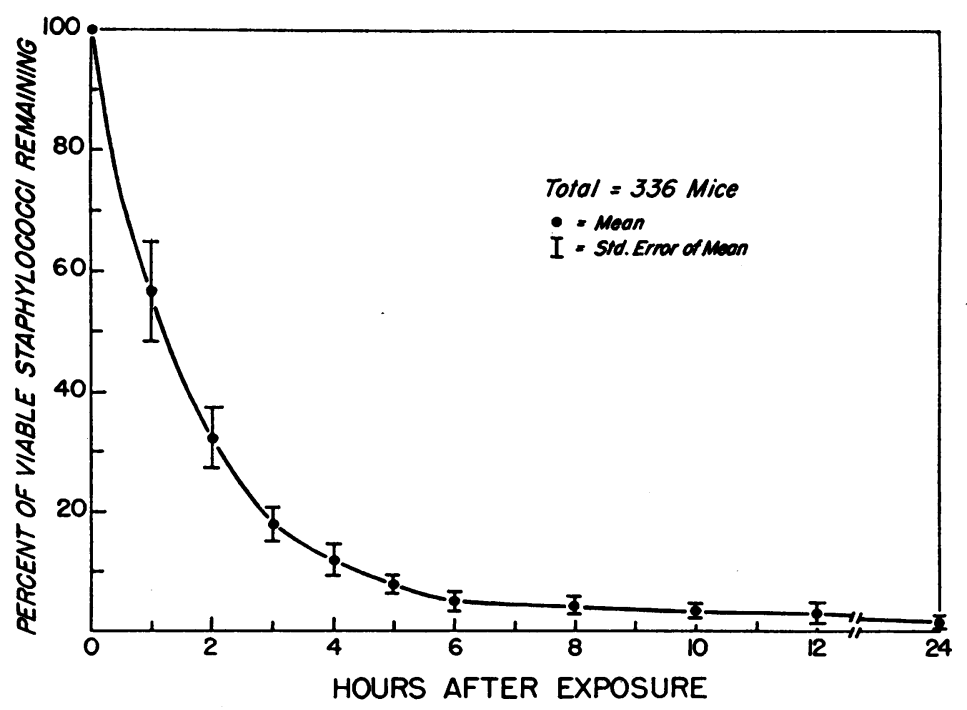

Fig. 6. Proportion of Staphylococci Cleared oR Made nonviable BY LUNGS OF MiCE AT VARIOUS TIME INTERVALS AFTER 30 MINUTES OF EXPOSURE TO AEROSOLS OF STAPHYLOCOCCI. 


\section{Discussion}

The generation of finely divided aerosols from fluid suspensions of bacteria closely resembles the natural processes whereby air is contaminated by microorganisms. In 1897, Flügge (15) demonstrated bacteria in droplets of moisture that were expelled from the respiratory tract by cough. Such droplets, if expelled into the air when the relative humidity is less than $100 \%$, evaporate almost immediately (16). The larger particles settle out on the surfaces in the vicinity of their source, but finer droplets persist as bacterial cells attached to small amounts of dried organic matter $(17,18)$. These are referred to as droplet nuclei, and in this state the bacteria may remain viable for hours.

The method herein presented provides a simple and reproducible technique for the study of infection of the respiratory tract through the use of aerosol techniques. The apparatus produces clouds with a high bacterial content which remains constant over a 30 -minute period and which results in the implantation of high numbers of organisms in the lungs of mice. The numbers of bacteria found in the murine lungs immediately after 30-minute exposure periods is dependent on bacterial numbers in the air. However, $10 \%$ of the inhaled bacteria was retained at $2.0 \times 10^{7}$ staphylococci per cubic foot of exposure chamber air, whereas $36 \%$ was retained when the air dose was $1.3 \times 10^{5}$ per cubic foot. It is probable that, at high air concentrations, bacterial agglomerates form when air passes through the mouth or nares and that these large aggregates are filtered out in the upper respiratory tract.

The decrease in the numbers of bacteria in the lungs of mice during the postexposure period demonstrates that the antibacterial activity of the lower respiratory tract is effective and rapid. Under the conditions of these studies bacterial clearance is predictable over a wide range of bacterial deposition. In this context, the term clearance refers to the process by which deposited bacteria become nonviable in the lungs or are removed from pulmonary tissue. In either case, clearance is used as an index of the total antibacterial activity of the lung.

The within and between variances and the standard error can be used to analyze the source of variability in the data. The over-all between variance is slightly smaller than the within variance, and it can therefore be suggested that the proportions of staphylococci cleared at a given time are not significantly different from run to run. Thus, the aerosol concentration has no detectable effect on the proportion of bacteria cleared within the ranges of the concentration studied. This fact argues that the major source of the antibacterial activity lies within a system or systems that have not approached saturation. The reproducibility of the clearance curves makes it possible to quantitate the effects of various circumstances on bacterial clearance, and studies demonstrating the adverse effects of various environmental circumstances have been undertaken in this laboratory.

Although the mucociliary stream is traditionally considered to be the main source of antibacterial activity in the lung, the size of the droplet nuclei generated in the present aerosol suggests that cells more distal to the bronchi may be involved in the mechanism. Unfortunately, relatively little is known about the rate of deposition of particles in alveoli of the size found in the broncho-alveolar system of the mouse. Hartroft (19) has studied the murine lung and shown that the alveolar dimensions are $\frac{1}{4}$ to $\frac{1}{5}$ those of the human lung. The alveolar orifice in mice measures approximately $35 \mu$ in diameter, the alveolar depth is approximately $40 \mu$, and the width is estimated as $38 \mu$ on the average. From these data, it would appear that the particle size and air space relationships are sufficient to suggest that there is no barrier to the entry of bacteria into alveoli, where their removal would involve the activity of alveolar macrophages. However, direct study to test this hypothesis is essential. The confirmation of this view would focus special attention on the functional activity of alveolar macrophages in contrast to the activities of the mucociliary stream.

\section{Summary}

An apparatus is described that allows the administration of predictable numbers of aerosolized bacteria to small animals. When staphylococci are nebulized from a phosphate buffer into the system described, with mice as the recipient animals, a linear relationship is established among 
bacterial concentrations in the buffer, bacterial concentrations in the air, and numbers of bacteria retained in the lungs of mice. After 30 minutes of exposure, colony counts in the range of $5-10 \times 10^{4}$ are found in the lungs of the mice. The bacteria disappear rapidly in the postexposure period, so that within 6 hours, $95 \%$ of the organisms that were originally found have disappeared. The pattern of clearance is quantitative and predictable, and the variation is surprisingly small. The size of the droplet nuclei generated in this apparatus suggests that a large share of the bacteria were deposited distal to the bronchial tree and thus raises the possibility that the antibacterial mechanisms which are responsible for the clearance of the bacteria may involve primarily the alveolar cells.

\section{Acknowledgments}

The authors are indebted to Dr. Gareth Green for his critical analysis and to Dr. Miles Davis for his statistical advice.

\section{References}

1. Brumfitt, W., M. L. N. Willoughby, and L. L. Bromley. An evaluation of sputum examination in chronic bronchitis. Lancet 1957, 2, 1306.

2. Lees, A. W., and W. McNaught. Bacteriology of lower respiratory secretions, sputum, and upper respiratory tract secretions in "normals" and chronic bronchitis. Lancet 1959, 2, 112.

3. Laurenzi, G. A., R. T. Potter, and E. H. Kass. Bacteriologic flora of the lower respiratory tract. New Engl. J. Med. 1961, 265, 1273.

4. Amberson, J. B. A clinical consideration of abcesses and cavities of the lung. Bull. Johns Hopk. Hosp. 1954, 94, 227.

5. Stillman, E. G. The presence of bacteria in the lungs of mice following inhalation. J. exp. Med. 1923, 38, 117.
6. Robertson, O. H. Phagocytosis of foreign material in the lungs. Physiol. Rev. 1941, 21, 112.

7. Wells, W. F. On air-borne infection. II. Droplets and droplet nuclei. Amer. J. Hyg. 1934, 20, 611.

8. Wells, W. F. Airborne Contagion and Air Hygiene. Cambridge, Harvard University Press, 1955.

9. Rosebury, T. Experimental Air-Borne Infection. Baltimore, Williams and Wilkins, 1947.

10. Lurie, M. B., A. G. Heppleston, S. Abramson, and I. B. Swartz. An evaluation of the method of quantitative airborne infection and its use in the study of the pathogenesis of tuberculosis. Amer. Rev. Tuberc. 1950, 61, 765.

11. Middlebrook, G. An apparatus for airborne infection of mice. Proc. Soc. exp. Biol. (N. Y.) 1952, 80, 105.

12. Laurenzi, G. A., and J. J. Guarneri. Unpublished observations.

13. Decker, H. M., J. B. Horstad, F. J. Piper, and M. E. Wilson. Filtration of microorganisms from air by glass filter media. Heating, Piping, Air Conditioning 1954, 26, 155.

14. May, K. R., and G. J. Harper. The efficiency of various liquid impinger samplers in bacterial aerosols. Brit. J. indust. Med. 1957, 14, 287.

15. Flügge, C. Ueber Luftinfektion. Z. Hyg. Infekt.Kr. 1897, 25, 179.

16. Respiratory exposure of animals to microorganisms with the Henderson apparatus. Safety division report no. 16 (2nd rev.). Ft. Detrick, Md., Safety Division and Technical Engineering Division, 1959.

17. Wells, W. F., H. L. Ratcliffe, and C. Crumb. On the mechanics of droplet nuclei infection. II. Quantitative experimental air-borne tuberculosis in rabbits. Amer. J. Hyg. 1948, 47, 11.

18. Bair, W. J. Deposition, retention, translocation, and excretion of radioactive particles in Inhaled Particles and Vapours, C. N. Davies, Ed. Oxford, England, Pergamon Press, 1961, p. 192.

19. Hartroft, W. S. The size of pulmonic alveoli of common laboratory animals and man (abstract). Amer. Rev. resp. Dis. 1960, 81, 734. 